\title{
Retrospective assessment of macrophytic communities in southern Lake Garda (Italy) from in situ and MIVIS (Multispectral Infrared and Visible Imaging Spectrometer) data
}

\author{
Mariano BRESCIANI, ${ }^{1,2^{*}}$ Rossano BOLPAGNI, ${ }^{2}$ Federica BRAGA,${ }^{3}$ Alessandro OGGIONI,${ }^{4}$ and Claudia GIARDINO ${ }^{1}$ \\ ${ }^{1}$ Optical Remote Sensing Group, CNR-IREA, Via Bassini 15, 20133 Milano, Italy; ${ }^{2}$ Department of Environmental Sciences, Parma \\ University, V.le Usberti 11/A, 43100 Parma, Italy; ${ }^{3}$ Institute of Marine Science, CNR- ISMAR, Arsenale Tesa 104, Castello 2737/F, \\ 30122 Venezia; ${ }^{4}$ Institute of Ecosystems Studies, CNR-ISE, Largo Tonolli 50, 28922 Verbania Pallanza, Italy \\ *Corresponding author: bresciani.m@irea.cnr.it
}

\begin{abstract}
In situ and hyperspectral MIVIS (Multispectral Infrared and Visible Imaging Spectrometer) images acquired over a period of 13 years are used to assess changes in macrophyte colonization patterns in the coastal zones of the Sirmione Peninsula in the southern part of Lake Garda (Italy). In situ data (abundance, cover density and diversity of macrophyte communities) and MIVIS-derived maps of colonized substrates are analyzed by considering the variability of the main hydrological and physicochemical variables in order to indicate the main factors that explain the spatiotemporal variability of macrophyte communities. The results show a considerable modification in terms of macrophyte structural complexity and colonized areas. Almost $98 \%$ of macrophyte meadows (in particular communities with a density of over 70\%) are lost and subsequently replaced by moderate to extremely rare communities with density from $10 \%$ to $40 \%$. Well-established submerged macrophytes are replaced by de-structured communities characterized by moderate to scarce density: on average lower than 30\%. The study indicates that macrophyte distribution along the littoral zone of the Sirmione Peninsula is certainly linked to water transparency and water level fluctuation. The results also indicate that the worsening of eutrophication may be associated with the gradual disappearance of macrophyte meadows, but may also be accelerated by herbivorous aquatic birds grazing there. Lastly, the increasing frequency and number of catamaran tours could be considered a threat for the stability of these valuable communities.
\end{abstract}

Key words: macrophytes, hyperspectral sensor, change detection, ecological determinants, Sirmione Peninsula.

Received: June 2011. Accepted: September 2011.

\section{INTRODUCTION}

Aquatic macrophytes play a crucial role in lentic ecosystems: the functional status of the littoral zones of lakes basically depends on the presence and spread of aquatic plants (i.e., vascular plants, bryophytes, stoneworts, and macro-algae) which actively contribute to regulating the nutrient cycle and maintaining the aquatic trophic chain (Scheffer, and Carpenter 2003; Scheffer, and Jeppesen 2007; Gacia et al. 2009). However, aquatic plant assemblages are highly vulnerable to anthropogenic perturbations and to other disturbance processes (i.e., watershed pollution, mechanical dredging, water abstraction, or alien species invasions) which frequently lead to the complete disappearance of submerged plant mats (Scheffer et al. 1993; Smart et al. 2002).

Within the context of macrophyte monitoring programs, technical advances in remote sensing with higher spatial and spectral resolutions provide opportunities for cost-effective qualitative and quantitative analyses of macrophytes with a synoptic view over large meadows, and for ecological investigations. Conversely, aquatic plants and their properties are not as easily detectable as terrestrial vegetation. Vis et al. (2003), however, demonstrated that remote sensing techniques are useful for investigating the shifts in the assemblages of primary producers by monitoring the distribution of aquatic macrophytes and changes in the layout of aquatic plant communities. As pointed out by a review of extant literature, major technical difficulties are met when vegetation is submerged or flooded; in fact the presence of water can alter the spectral characteristics of the images (an exhaustive discussion is presented in Silva et al. 2008).

Most remote sensing technologies and processing techniques have been developed and used to assess the structural, functional, ecological, etc. properties of macrophytes; on the other hand, the application of these different technologies and methodologies is limited by the complexity of the ecosystem (i.e., morphology, hydrodynamics, ecology; Orth, and Moore 1983; Duarte 1987). With adequate repeatability, airborne and satellite sensor data can be used for multi-temporal studies and they provide reliable information for understanding the ecological dynamics of macrophytes, through the analysis of intra- 
and inter-seasonal patterns or spatial landscape trends or changes (Fonseca et al. 2002). Furthermore, some biophysical and physiological vegetation features (i.e., biomass, cover percentages, structural stand complexity and composition and the physiological status of vegetation) can be detected and estimated from specific spectral properties of reflectance spectra (Fyfe 2003; and references therein). In addition, these parameters enable us to assess the environmental status and the biodiversity of the meadows studied, and also use them as input data for ecosystem models (e.g., for determining the habitat for organisms that depend on seagrass) (Bell et al. 2006; Duffy et al. 2006; Gillanders 2006). Consequently, remote sensing can support accurate and repeatable methods for meadow condition monitoring and assessment, in compliance with certain European Directive strategic objectives [i.e., the Habitat Directive (92/43/EEC) and the Water Framework Directive (2000/60/EC)]. In particular, Directive 2000/60/EC needs to know the abundance of aquatic plants in order to define the deviation from the ecological conditions of reference. The sampling protocols proposed in Europe (e.g., Jaeger et al. 2004; Schaumburg et al. 2007; Oggioni et al. 2011) require great efforts to detect the actual presence of macrophyte areas, and such efforts become prohibitive in large, deep lakes. Developing effective approaches to mapping macrophyte properties would provide baseline data sets for such applications. Many studies have therefore attempted to identify optimal approaches to image processing for a comprehensive analysis of macrophyte ecology (Jakubauskas et al. 2000; Buchan, and Padilla 2000; Ozesmi, and Bauer 2002; Heblinski et al. 2010). The reliability of an integrated remote sensing data and field survey method for mapping macrophyte properties and for assessing the biodiversity of aquatic plant environments is evaluated in Phinn et al. (2008). In this case, the properties mapped (i.e., the composition, percentage cover and biomass of seagrass species) were obtained by means of different sensors. The greater degree of accuracy was achieved from hyperspectral airborne image data: multispectral sensors often used previously were unable to discriminate macrophyte species and to differentiate low levels of cover. Barillé et al. (2010), on the other hand, built spatial macrophyte distribution maps for the French coast over a 14-year period with multispectral imagery, analyzing the extent of macrophyte mats and changes in abundance with respect to local anthropogenic drivers and coastal land use. They proposed a quantitative relationship between the Normalized Difference Vegetation Index (NDVI) and the dry weight of leaves in order to obtain a biomass distribution map. Lastly, Hunter et al. (2010) classified macrophyte growth habits and discriminated submerged species in clear-water shallow lakes with airborne hyperspectral data. The lakes studied are situated in a large British protected wetland and the study provides an evaluation of the potential use of remote sensing data in support of ecological and conservation waterbody assessment status.

The experimental evidence discussed here (collected within the context of medium- and large-scale ecological and conservation programs) suggested that established regional-scale macrophyte habitat mapping could provide an adequate baseline for further large-scale management programs and research actions (Wabnitz et al. 2008). On a global scale, for example, Dierssen et al. (2010) used ocean color remote sensing techniques for determining the role of macrophytes in the global carbon cycle by mapping abundance and distribution of different types of benthic habitats and their changes. Their main result was to have found a logarithmic relationship between net primary productivity and green seafloor reflectance which describes the general trend across various benthic constituents. In the light of these remarks was started a long term research program with the aim to monitor the macrophyte beds evolution in the lake Garda, the biggest Italian internal basin. In this paper, we will examine in detail the: i) the variations in the representativeness of macrophyte communities (in terms of area colonized) in Italy's largest lake from hyperspectral airborne data acquired during the summers of 1997, 2005 and 2010,

ii) the biomass patterns in relation to the main physical features and management strategies of the water basin, iii) the lake's trophic tendencies.

\section{MATERIALS AND METHODS}

\section{Study site}

Lake Garda is one of several subalpine lakes and is the largest freshwater basin in Italy. It is characterized by great depths $(360 \mathrm{~m})$ and large volumes $\left(49 \mathrm{~km}^{3}\right)$. Lake Garda contains $30 \%$ of Italy's whole natural and artificial lake water resources (Salmaso, and Mosello 2010). Lake Garda belongs to a distinct typology of Italian subalpine lakes located on the southern edge of the Alps, with a surface of $368 \mathrm{~km} 2$. The Garda basin (mean altitude $=65 \mathrm{~m}$ a.s.l.) occupies a deep fluvial valley originated during the superior Miocene (5-6 million years BP) modified during the successive Quaternary glaciations (Salmaso et al. 2009, and citations herein). The catchment of Lake Garda is relatively small in relation to the lake area (6:1) and is mainly composed of sedimentary rocks $(60 \%)$, while both crystalline rocks and secondarily deposited glacial and fluvial sediments both account for $20 \%$ (Sauro 2001).

The theoretical retention time of Lake Garda is 26.6 years and the lake is classified as warm monomictic and oligomictic, since water mixing occurs once in late winterearly spring and usually only involves the upper 150$200 \mathrm{~m}$ of the water column. Complete water circulation occurs at irregular intervals in connection with exception- 
ally cold winters (Salmaso et al. 2009). According to recent limnological investigations, the Lake Garda basin presents a stable trend in an oligo-mesotrophic condition (Salmaso, and Mosello 2010).

Lake Garda is also an essential renewable resource for the surrounding environment, the most densely populated and industrialized in Italy, due to the multiple uses of its waters (human consumption, irrigation, energy, transportation, recreational purposes).

In particular, the Sirmione Peninsula, located at the southern end of the lake (Fig. 1), is one of the most popular tourist destinations in Italy. The Sirmione Peninsula extends for about $4 \mathrm{~km}$ into the lake and its shores are characterized by moderate slopes inhabited by diverse species of aquatic phanerogams. Communities of Phragmites australis (Cav.) Trin. ex Steud. subsp. australis can be found in less urbanized areas, while a variety of macrophytes colonise the substrates surrounding the peninsula. The most common species are Chara globularis Thuillier 1799, Vallisneria spiralis L., Lagarosiphon major (Ridl.) Moss, and several taxa of the Potamogeton genera. Overall, the dominant floristic contingent is composed by: $\mathrm{Cer}$ atophyllum demersum L., Elodea canadensis Michx., Groenlandia densa (L.) Fourr., Myriophyllum spicatum L., Najas marina L. subsp. marina, Potamogeton crispus L., P. pusillus L., and Ranunculus fluitans Lam. The water levels along the peninsula are influenced by the weather and by the regulation of the flow of the river Mincio. In the Sirmione area there are several small streams that enter the turbid waters in the coastal zone. A previous study by Giardino et al. (2007a) describes the cover trend of macrophyte meadows between 1997 and 2005.

\section{Image processing}

Hyperspectral airborne images were acquired with the whisk-broom scanner Multispectral Infrared and Visible Imaging Spectrometer (MIVIS). MIVIS works in 102 spectral channels, spanned from $0.43 \mu \mathrm{m}$ to $12.68 \mu \mathrm{m}$, where four different spectrometers detect electromagnetic radiation. In particular, the first spectrometer, with 20 spectral channels from $430 \mathrm{~nm}$ to $830 \mathrm{~nm}$, is important for water quality applications. With an instantaneous field of view of $2 \mathrm{~m}$ rad and operational flight heights between 1500 and $5000 \mathrm{~m}$, the pixel dimension of MIVIS images ranges from 3 meters up to 10 meters (Cavazzini et al. 2000).

Three MIVIS images of the study area were acquired on 16 September 1997, on 27 July 2005 and on 15 July 2010 , all of them with a spatial resolution of $5 \times 5 \mathrm{~m}$. We assume that the time difference in acquiring the images (in particular between the first image acquired at the end of the macrophyte development period and the following two images referred to midlate July) does not significantly affect the relevance of image comparison. Several au-

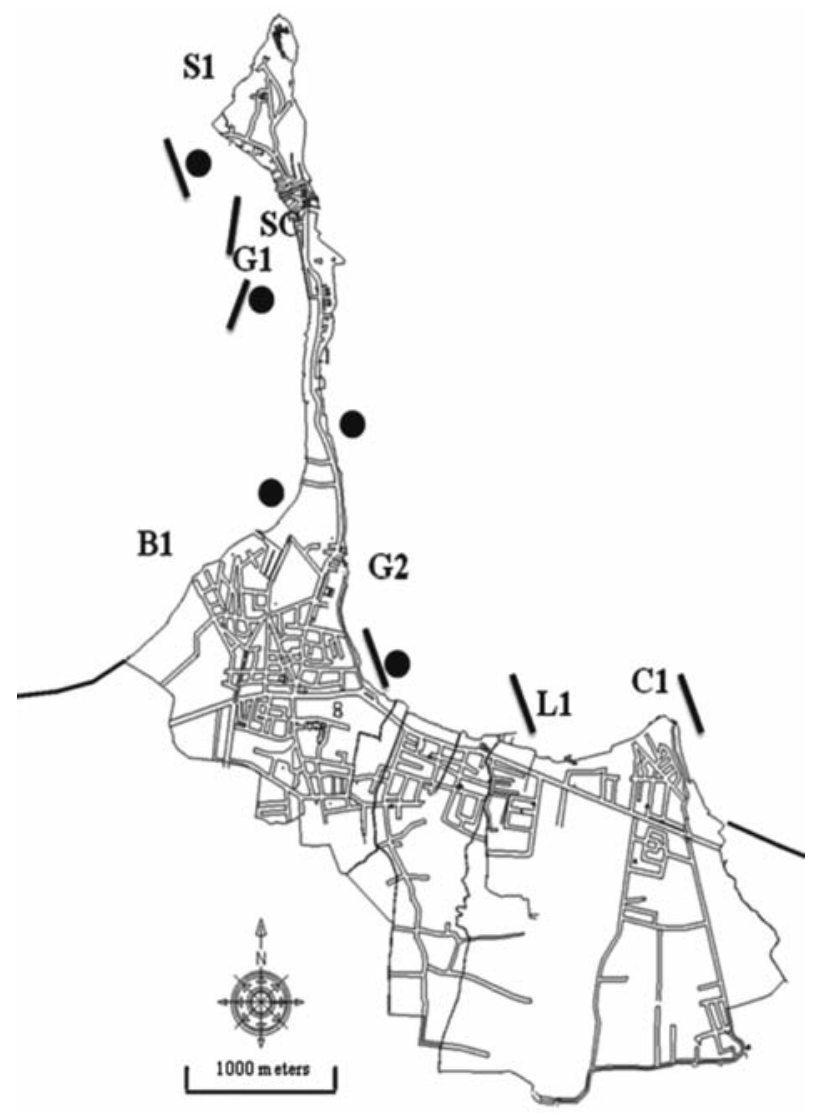

Fig. 1. Map of the study area showing sampling stations of physic-chemical data: Sirmione Castle (SC) Garden (G1), Cantarane (C1), Lugana (L1), Staffalo (S1), Galeazzi (G2), and Brema (B1). in situ sampling of macrophyte transects (black line) and radiometric measurements (black circle) are also indicated.

thors, in fact, reported data that highlighted how July-August is the period of maximum rhizophyte biomass in temperate regions (Vis et al. 2003; Bolpagni et al. 2007) where usually plant senescence only starts at the end of September (Bolpagni et al. 2007; Pierobon et al. 2010).

The maps of bottom depth and submerged macrophytes in the study area were produced as described by Giardino et al. (2007a) with procedures to correct for atmospheric effects and to invert a bio-optical model. In particular, MIVIS data were atmospherically corrected with the 6S code (Second Simulation of the Satellite Signal in the Solar Spectrum) (Vermote et al. 1997; Kotchenova et al. 2006; Kotchenova, and Vermote 2007). The bio-optical model was parameterized with inherent optical properties. Bottom albedo values of lake Garda (Giardino et al. 2007a, b), were inverted with an optimisation technique (Giardino et al. 2008). For each date, images of bottom depth and the percentage of sand with respect to vegetation (or vice versa) were produced. Then, to support the ecological analysis of changes in macrophyte coloni- 
sation patterns, four classes of submerged vegetation distribution within the pixel (i.e., the density of the community) were mapped.

\section{Fieldwork and Supporting Data}

Macrophyte cover was estimated visually during the airborne acquisition from June to September 2005 and 2010 at 18 points located along six transects laid out perpendicular to the shore at the littoral belt (Fig. 1); that is, $\sim 60-80$ meters from the starting point of the riparian survey sites. Transects are identified in order to cover local macrophyte vegetation variability, and to evaluate the accuracy of MIVIS over-flight. Dive data were collected using a $0.25 \mathrm{~m}^{2}$ hoop randomly positioned above the macrophytic meadow. All plants presented in the hoop were collected and, once in the laboratory, gently washed to remove periphyton; afterwards, we calculated the cover-abundance values which are specific to the species. In order to address this issue, we used exclusively cover values at community level, ranked as sand (bare sediments devoid of plants), sparse $(0-10 \%$ cover $)$, moderate (10-40\% cover), dense (40-70\% cover) and extensive (>70\%) macrophyte cover.

In spite of the coarse macrophyte cover estimation provided by this rapid assessment procedure, it seems to be a relatively quick and inexpensive technique for generating robust datasets at different geographical levels. The study of the diachronic evolution of macrophyte diversity was conducted on the basis of six distribution classes to describe the rarity or commonness of macrophytes in Lake Garda (Tab. 1).

No specific historical records are available for Lake Garda's flora. Despite that, we can highlight the main transformation processes in the diversity and relative abundance of plant species on the basis of data provided by Bianchini et al. (1974), Wiegleb (1983), Borsani et al. (2000), Ludovisi et al. (2004), Bolpagni (2005, unpublished data) and this work. These data allowed for a general diachronic comparison of the hydrophytic contingent in the study area over the last 35 years, namely in the period of the major changes of the trophic status of Lake Garda as highlighted by Salmaso $(2005,2010)$ and Salmaso, and Mosello (2010).

Tab. 1. Classification of relative occurrence of macrophytes.

\begin{tabular}{lc}
\hline Distribution class & $\begin{array}{c}\text { Range } \\
\% \text { of a taxon in the dataset) }\end{array}$ \\
\hline Dominant (d) & $>75$ \\
Abundant (a) & $50-75$ \\
Common (c) & $25-50$ \\
Uncommon (uc) & $5-25$ \\
Rare (r) & $1-5$ \\
Very rare (vr) & $0-1$ \\
\hline
\end{tabular}

As regards physical and physicochemical data acquisition, water transparency was measured by means of a Secchi disk, dissolved oxygen was measured with the Winkler method while $\mathrm{pH}$, conductivity and temperature were acquired with field probes; the water level was measured by a hydrometer located at the Sirmione castle gate. The data set was collected by the CRA (Centro di Rilevamento Ambientale) and ASL (Azienda Sanitaria Locale) Brescia Sirmione at different stations (Fig. 1) located 300 meters from the coastline in the period between April and October.

\section{RESULTS}

Physical and physicochemical data

The following description refers to the inter-annual evolution trends of physical and physicochemical features within the temporal limits of the macrophyte development phase (between April and October).

In the last 13-year period (1997-2010), the water transparency (WT) of the southern portion of Lake Garda featured three distinct phases: i) a highly variable initial phase (from 1995 to 2000) in which water transparency ranged between a peak of $8.8 \pm 1.1 \mathrm{~m}$ (1997) and a minimum value of $4.9 \pm 1.3 \mathrm{~m}$ (1997) (mean values \pm dev st) (Tab. 2, Fig. 2); ii) from 2001 to 2005 , data reveal an overall mean stability of $6.0 \pm 0.4 \mathrm{~m}$; iii) and a final phase characterized by moderately high values of about $7.0 \pm 0.3 \mathrm{~m}$ (Tab. 2). As regards water level fluctuations (WLF) (measured as the difference between maximum and minimum WL value), between 1995 and 2004, levels in Lake Garda were moderately stable with a inter-annual mean of $94 \pm 17$ $\mathrm{cm}$ above hydrometric zero, whereas a dramatic reduction in the water level was highlighted in the three-year period 2005-2007 (53 $\pm 19 \mathrm{~cm}$ above hydrometric zero); by contrast, the last three years (2008-2010) were characterized by a considerable water level increase up to a mean value of $116 \pm 3 \mathrm{~cm}$ above hydrometric zero (Tab. 2).

The mean annual temperature (Tab. 3) has slightly increased over the last 13 years as suggested by regression statistics of the T mean values versus time $\left(\mathrm{r}^{2}=0.32\right.$, slope $>0, * P$ value $=0.02)$; moreover over the same time period the standard deviation associated to mean annual temperatures significantly decreases meaning a reduction of variability of the intra-annual values. The same statistical analyses applied to minimum and maximum temperatures highlighted non significant trends over the years. No trend is also observed for the mean dissolved oxygen ( $P$ value $=0.195$ ) that ranges between a minimum of $95.7 \pm 1.6 \%$ in 2003 and a maximum of $115.4 \pm 2.4 \%$ in 2010. $\mathrm{pH}$ values were extremely homogeneous with an inter-annual global mean equal to $8.58 \pm 0.14 \mathrm{pH}$ units, whereas conductivity (ranging between 310 and $213 \mu \mathrm{S}$ 
$\mathrm{cm}^{-1}$ for 2002 and 2010, respectively) showed a moderate level of variability, always ranging between 12 and 19\% of the maximum value (Tab. 3).

A significant negative correlation $\left(r=0.62,{ }^{*} P\right.$ value $=0.010$ ) was found between the mean values of WT and WLF. Moreover, the WLF showed a good agreement with the mean values of dissolved oxygen $(r=0.74, * * P$ value $=0.001)$ and $\mathrm{pH}(r=0.59, * P$ value $=0.014) . \mathrm{WLF}$ delta was also positive correlated with the water temperature fluctuations $(r=0.60, * P$ value $=0.017)$.

Diachronic evolution of macrophyte diversity and abundance

Comparing floristic data available since 1974, it can be seen that there is a slight decrease in species diversity up to 2010 (20 vs 16 species), mainly in the southern por-

Tab. 2. Physical features (mean \pm standard deviation) of the study area; water transparency (i.e., average values of Secchi Disk depth at 6 different sampling stations, cf. G1, C1, L1, S1, G2 and B1 in Fig. 1) and water level above the hydrometric zero (measured at station $\mathrm{SC}$ in Fig. 1). Maximum ( $\max$ ), minimum ( $\mathrm{min}$ ) values and the range of variation delta $\Delta$ (i.e., difference between maximum and minimum data) are reported together with the number of measures (n). Rows highlighted in pale grey identify the years of airborne campaigns. *Data provided are referred to the period April to October that corresponds to the macrophyte stands development phases.

\begin{tabular}{|c|c|c|c|c|c|c|c|c|c|}
\hline \multirow[b]{2}{*}{ year* } & \multirow[b]{2}{*}{$\mathrm{n}$} & \multicolumn{4}{|c|}{ Water transparency (m) } & \multicolumn{4}{|c|}{ Water level $(\mathrm{cm})$} \\
\hline & & mean \pm st. dev. & $\max$ & $\min$ & $\Delta$ & mean \pm st. dev. & $\max$ & $\min$ & $\Delta$ \\
\hline 1995 & 38 & $6.1 \pm 1.9$ & 8.3 & 4.3 & 4.0 & $107 \pm 19$ & 141 & 77 & 64 \\
\hline 1996 & 19 & $7.2 \pm 1.2$ & 9.7 & 4.5 & 5.2 & $66 \pm 11$ & 92 & 54 & 38 \\
\hline 1997 & 12 & $8.0 \pm 1.1$ & 10.0 & 3.7 & 6.3 & $101 \pm 19$ & 136 & 75 & 61 \\
\hline 1998 & 18 & $7.7 \pm 1.0$ & 9.8 & 4.8 & 4.9 & $104 \pm 14$ & 125 & 77 & 48 \\
\hline 1999 & 34 & $6.0 \pm 1.8$ & 8.6 & 3.2 & 5.4 & $105 \pm 19$ & 125 & 74 & 51 \\
\hline 2000 & 41 & $4.9 \pm 1.3$ & 9.0 & 2.0 & 7.0 & $78 \pm 24$ & 122 & 51 & 71 \\
\hline 2001 & 32 & $6.8 \pm 1.1$ & 8.7 & 3.5 & 5.2 & $99 \pm 20$ & 129 & 70 & 59 \\
\hline 2002 & 35 & $6.1 \pm 1.4$ & 8.5 & 1.8 & 6.7 & $105 \pm 54$ & 125 & 48 & 77 \\
\hline 2003 & 16 & $5.6 \pm 2.0$ & 9.0 & 2.5 & 6.5 & $68 \pm 42$ & 116 & 8 & 108 \\
\hline 2004 & 27 & $5.9 \pm 0.4$ & 7.0 & 4.7 & 2.3 & $108 \pm 22$ & 132 & 47 & 85 \\
\hline 2005 & 21 & $5.6 \pm 0.8$ & 7.3 & 3.8 & 3.5 & $51 \pm 28$ & 87 & 17 & 70 \\
\hline 2006 & 32 & $6.0 \pm 0.9$ & 8.3 & 5.0 & 3.3 & $73 \pm 21$ & 95 & 40 & 55 \\
\hline 2007 & 13 & $7.0 \pm 0.6$ & 8.5 & 5.7 & 2.8 & $35 \pm 19$ & 62 & 10 & 52 \\
\hline 2008 & 18 & $7.0 \pm 0.6$ & 8.2 & 6.0 & 2.2 & $115 \pm 17$ & 135 & 85 & 50 \\
\hline 2009 & 11 & $6.6 \pm 0.7$ & 8.3 & 5.2 & 3.2 & $114 \pm 19$ & 131 & 79 & 52 \\
\hline 2010 & 8 & $7.3 \pm 1.4$ & 8.8 & 3.5 & 5.3 & $119 \pm 14$ & 131 & 90 & 41 \\
\hline
\end{tabular}

Tab. 3. Physical-chemical features (mean \pm standard deviation, $m \pm$ st. dev.) of the study area. Maximum (max), minimum (min) values and the range of variation measured as the difference between maximum and minimum data $(\Delta$, delta) for four parameters are reported. Temperature, Oxygen and $\mathrm{pH}$ were collected in the same places and with the same frequency of WT data (cf. Tab. 2 and Fig. 1); conductivity was collected every 3 day at S1 station (cf. Fig. 1). Rows highlighted in pale grey identify the years of the airborne data. $\uparrow$ data provided are referred to the period April to October that corresponds to the macrophyte stands development phases; *for 2000 and 2010 temperature values were measured exclusively at the Punta Staffalo Station by CRA.

\begin{tabular}{|c|c|c|c|c|c|c|c|c|c|c|c|c|c|c|c|c|}
\hline \multirow[b]{2}{*}{ year† } & \multicolumn{4}{|c|}{ Temperature $\left({ }^{\circ} \mathrm{C}\right)$} & \multicolumn{4}{|c|}{ Oxygen (\%) } & \multicolumn{4}{|c|}{$\mathrm{pH}$} & \multicolumn{4}{|c|}{ Cond $\left(\mu \mathrm{S} \mathrm{cm}^{-1}\right)$} \\
\hline & $\mathrm{m} \pm$ st. dev. & $\max$ & $\min$ & $\Delta$ & $\mathrm{m} \pm$ st. dev. & $\max$ & $\min$ & $\Delta$ & $\mathrm{m} \pm$ st. dev. & $\max$ & $\min$ & $\Delta$ & $\mathrm{m}$ & $\max$ & $\min$ & $\Delta$ \\
\hline 1995 & $19.5 \pm 1.0$ & 28.0 & 9.0 & 19.0 & $106.0 \pm 1.9$ & 119.7 & 87.0 & 32.7 & $8.40 \pm 0.04$ & 8.79 & 7.82 & 0.97 & & & $d$ & \\
\hline 1996 & $19.5 \pm 0.8$ & 24.0 & 9.0 & 15.0 & $103.2 \pm 2.4$ & 120.0 & 80.2 & 39.8 & $8.30 \pm 0.08$ & 8.74 & 7.80 & 0.94 & & & $\mathrm{~d}$ & \\
\hline 1997 & $19.6 \pm 0.4$ & 26.0 & 10.0 & 16.0 & $108.0 \pm 3.2$ & 156.3 & 83.3 & 73.0 & $8.62 \pm 0.04$ & 8.88 & 8.28 & 0.60 & & & $d$ & \\
\hline 1998 & $19.8 \pm 0.9$ & 27.0 & 10.0 & 17.0 & $107.5 \pm 1.7$ & 134.9 & 90.6 & 44.3 & $8.47 \pm 0.04$ & 8.85 & 8.20 & 0.65 & & & $\mathrm{~d}$ & \\
\hline 1999 & $20.3 \pm 1.1$ & 26.0 & 12.0 & 14.0 & $108.4 \pm 3.5$ & 156.9 & 72.3 & 84.6 & $8.61 \pm 0.05$ & 8.97 & 7.98 & 0.99 & & & $\mathrm{~d}$ & \\
\hline $2000 *$ & $20.4 \pm 1.3$ & 26.8 & 10.0 & 16.8 & $105.6 \pm 2.2$ & 133.2 & 82.1 & 51.1 & $8.68 \pm 0.04$ & 8.98 & 8.14 & 0.84 & 258 & 342 & 227 & 115 \\
\hline 2001 & $18.6 \pm 0.9$ & 25.0 & 10.0 & 15.0 & $102.5 \pm 1.6$ & 114.0 & 88.0 & 26.0 & $8.63 \pm 0.11$ & 9.00 & 8.00 & 1.00 & 278 & 385 & 217 & 168 \\
\hline 2002 & $19.5 \pm 0.7$ & 26.0 & 11.0 & 15.0 & $97.8 \pm 1.8$ & 119.0 & 82.0 & 37.0 & $8.74 \pm 0.05$ & 9.00 & 8.20 & 0.80 & 310 & 363 & 275 & 88 \\
\hline 2003 & $18.7 \pm 1.0$ & 27.0 & 7.0 & 20.0 & $95.7 \pm 1.6$ & 111.0 & 62.0 & 49.0 & $8.74 \pm 0.03$ & 9.00 & 8.50 & 0.50 & 269 & 389 & 237 & 152 \\
\hline 2004 & $20.7 \pm 0.7$ & 26.0 & 8.0 & 18.0 & $99.2 \pm 1.7$ & 117.0 & 90.0 & 27.0 & $8.59 \pm 0.05$ & 8.97 & 8.29 & 0.68 & 291 & 415 & 242 & 173 \\
\hline 2005 & $20.0 \pm 0.5$ & 26.0 & 10.0 & 16.0 & $108.9 \pm 1.8$ & 119.0 & 95.0 & 25.0 & $8.67 \pm 0.02$ & 8.91 & 8.48 & 0.43 & 269 & 427 & 162 & 265 \\
\hline 2006 & $19.0 \pm 1.2$ & 27.0 & 10.0 & 17.0 & $112.5 \pm 0.8$ & 131.0 & 100.0 & 31.0 & $8.68 \pm 0.02$ & 8.98 & 8.20 & 0.78 & 267 & 445 & 235 & 210 \\
\hline 2007 & $21.1 \pm 0.1$ & 25.0 & 11.0 & 14.0 & $108.2 \pm 1.1$ & 122.0 & 94.0 & 28.0 & $8.69 \pm 0.01$ & 8.99 & 8.42 & 0.57 & 258 & 402 & 187 & 215 \\
\hline 2008 & $20.6 \pm 0.1$ & 26.0 & 10.0 & 16.0 & $108.2 \pm 2.0$ & 118.0 & 92.0 & 26.0 & $8.67 \pm 0.03$ & 8.88 & 8.31 & 0.57 & 214 & 300 & 162 & 138 \\
\hline 2009 & $22.0 \pm 0.4$ & 27.7 & 11.4 & 16.3 & $108.7 \pm 3.3$ & 137.0 & 11.0 & 126.0 & $8.39 \pm 0.09$ & 8.63 & 8.25 & 0.38 & 217 & 310 & 189 & 121 \\
\hline $2010 *$ & 21.4 & 27.8 & 11.2 & 16.6 & $115.4 \pm 2.4$ & 150.0 & 102.0 & 48.0 & $8.37 \pm 0.03$ & 9.02 & 7.85 & 1.17 & 213 & 325 & 153 & 172 \\
\hline
\end{tabular}



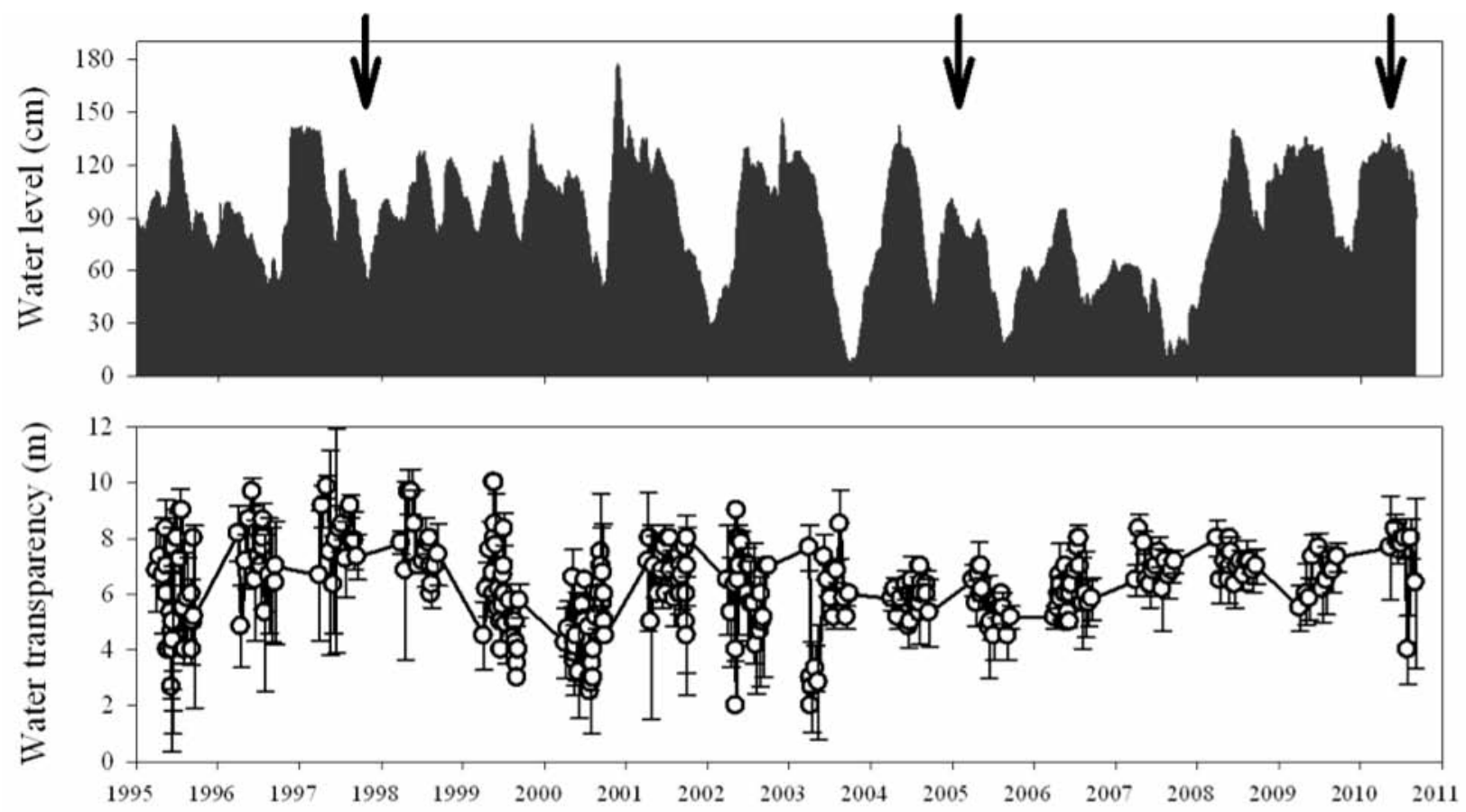

Fig. 2. Inter-annual evolution of water level (continuous data from January 1995 to October 2010) and water transparency (data provided are referred to the period April to October that corresponds to the macrophyte stands development phases from April 1995 to October 2010); black arrows pointed the years of the airborne surveys.

Tab. 4. Diachronic data of the presence and relative occurrence of macrophytes in Lake Garda; for abbreviations see Table 1 (studies specifically covering the littoral zone of the Sirmione Peninsula are highlighted in pale gray).

\begin{tabular}{|c|c|c|c|c|c|c|}
\hline & $\begin{array}{c}\text { ianchini et al. } \\
1974\end{array}$ & Wiegleb 1983 & $\begin{array}{c}\text { Borsani et al. } \\
2000\end{array}$ & $\begin{array}{l}\text { Ludovisi et al. } \\
2004\end{array}$ & Bolpagni 2005 & this work 2010 \\
\hline Ceratophyllum demersum L. & $\mathrm{d}$ & $\mathrm{d}$ & a & & $\mathrm{c}$ & $\mathrm{c}$ \\
\hline Chara sp. & $\mathrm{d}$ & & $\mathrm{d}$ & a & & \\
\hline Chara globularis Thuillier 1799 & & $\mathrm{~d}$ & $\mathrm{~d}$ & & a & a \\
\hline Elodea canadensis Michx. & a & $\mathrm{r}$ & & & & \\
\hline Groenlandia densa (L.) Fourr. & a & uc & & & & \\
\hline Lagarosiphon major (Ridl.) Moss & $\mathrm{vr}$ & $\mathrm{c}$ & $\mathrm{c}$ & $\mathrm{d}$ & $\mathrm{d}$ & $\mathrm{d}$ \\
\hline Lemna minor $\mathrm{L}$. & uc & & & & & \\
\hline Myriophyllum spicatum $\mathrm{L}$. & d & $\mathrm{d}$ & $\mathrm{c}$ & uc & uc & $\mathrm{c}$ \\
\hline Najas marina L. subsp. marina & a & c & $\mathrm{a}$ & & uc & c \\
\hline Najas minor All. & & & $\mathrm{c}$ & & vr & $\mathrm{vr}$ \\
\hline Nitella sp. & $\mathrm{r}$ & & $\mathrm{vr}$ & & & \\
\hline Persicaria amphibia (L.) Delarbre & uc & & & & & \\
\hline Potamogeton alpinus Balbis & & $\mathrm{r}$ & & & & \\
\hline Potamogeton crispus $\mathrm{L}$. & $\mathrm{d}$ & a & & & & $\mathrm{vr}$ \\
\hline Potamogeton lucens $\mathrm{L}$. & $\mathrm{c}$ & c & & & & $\mathrm{vr}$ \\
\hline Potamogeton pectinatus L. & a & c & & a & $\mathrm{a}$ & a \\
\hline Potamogeton perfoliatus $\mathrm{L}$. & $\mathrm{d}$ & $\mathrm{d}$ & $\mathrm{d}$ & $\mathrm{c}$ & a & a \\
\hline Potamogeton pusillus L. & a & $\mathrm{c}$ & d & & & uc \\
\hline Potamogeton trichoides Cham. \& Schltdl. & & & vr & & & $\mathrm{r}$ \\
\hline Ranunculus fluitans Lam. & d & & & & & \\
\hline Ranunculus trichophyllus Chaix subsp. trichophyllus & & & & & $\mathrm{r}$ & $\mathrm{r}$ \\
\hline Vallisneria spiralis $\mathrm{L}$. & d & d & d & $\mathrm{c}$ & a & d \\
\hline Zannichellia palustris L. subps. polycarpa (Nolte) K. Richt. & ht. c & uc & & & c & c \\
\hline Fontinalis antipyretica Hedw. & uc & & & & $\mathrm{r}$ & $\mathrm{r}$ \\
\hline Fissidens fontanus (La Pyl.) Steud. & $\mathrm{vr}$ & & & & & \\
\hline Rhynchostegium riparioides (Hedw.) C. E. O. Jensen & & $\mathrm{r}$ & & & & \\
\hline Total species & 20 & 16 & 12 & 6 & 12 & 16 \\
\hline
\end{tabular}


tion of the basin (Tab. 4). Furthermore, the relative occurrence data show plant stand changes in greater detail. Several species have experienced a profound population decline among the pristine dominant taxon categories (Tab. 4). In particular, E. canadensis, G. densa and R. fluitans were no longer recorded in the last twenty years, at least in the southern portion of the basin (Ciutti et al. 2011). By contrast, the relative abundance values of $C$. globularis, Potamogeton pectinatus L., P. perfoliatus L. and Vallisneria spiralis did not vary significantly during the period studied. These species constitute the main component of Lake Garda's submerged vegetation, although in the last 5 years a remarkable recovery of the following species Potamogeton crispus L., P. lucens L., P. pectinatus, Zannichellia palustris L. subsp. polycarpa (Nolte) K. Richt., and Ranunculus trichophyllus L. subsp. trichophyllus was observed in the pioneer stands.

Interannual macrophyte and sediment cover trends

Our data suggest huge modifications in terms of colonized areas and the structural complexity of submersed primary producer communities (Figs 3 and 4). Since 1995, we have observed that almost $98 \%$ of extensive macrophyte meadows (including communities with density higher than 70\%) have been lost and sub-sequently replaced by moderate to sparse communities with cover values of between $10 \%$ and $40 \%$. By contrast, the uncolonized area showed an initially dramatic increase from $28 \%$ to $53 \%$ between 1997 and 2005 to then rapidly decrease in the following 5 years to $35 \%$ (between 2005 and 2010) (Fig. 4).

In the period studied, also the bottom depths revealed variations that are not negligible in terms of plant colonization efficiency. On the whole, both relative maximum depths (ranging between 5 and $7 \mathrm{~m}$ ) and minimum depths (ranging between 0 and $2 \mathrm{~m}$ ) changed their plant colonization representativeness passing from $\sim 5 \%$ to $\sim 30 \%$ and from $\sim 50 \%$ to $10 \%$ of the total area investigated, respectively; by contrast, plant colonized intermediate depths (ranging between 3 and $5 \mathrm{~m}$ ) showed relative constancy during the investigation period ( $20 \%)$ (Fig. 3).

\section{DISCUSSION}

During the study period (1997-2010), data revealed a considerable loss in both relative macrophyte abundance (Tab. 4) and cover density (Fig. 3a) coupled with a progressive deepening of plant-colonized substrates in the littoral area of the Sirmione Peninsula (Figs $3 b$ and 4).

Overall, pristine well-developed submerged communities (dominated by a relatively rich group of species, including C. globularis, M. spicatum, P. perfoliatus, and $V$. spiralis were the dominant and the wide-spread taxa on a local scale) were thereafter replaced by destructured com- munities characterized by moderate to scarce cover-abundance values that are, on average, lower than 30\% (Fig. $3 b)$. Otherwise, in the last 5 years (2005-2010) submerged plant communities displayed exclusively slight differences in terms of dominant species with respect to the reference data (1974), with the exception of a dramatic increase in cover-abundance values of $L$. major and the complete disappearance of E. canadensis and G. densa. At moderate depths $(0-6 \mathrm{~m})$ the dominant native species are often replaced by $L$. major which is able to adapt to freshwater ecosystems characterized by nonequilibrial steady conditions produced by stress and/or external perturbations (Shea, and Chesson 2002; Capers et al. 2007). Several studies have demonstrated, in fact, how competition is a minor driving factor in submerged plant communities with respect to stress and disturbance (i.e., waves, sediment re-suspension, water level fluctuations, grazing waterfowl, fish, boats and navigation impacts) (Jupp, and Spence 1977; Murphy, and Eaton 1983; Lodge 1991; McCreary 1991; Wilson, and Keddy 1991). Integrative data concerning herbivorous aquatic birds (swans, wild ducks and coots) and fish assemblages and the number of catamarans operating in the Sirmione Peninsula area (as an indicator of the impact of recreation and tourism activities) were collected for the study period (data provided by Ebnitalia, Confortini I. Province of Verona and CRA Sirmione). Faunal data show a significant increase in winter bird numbers up to 2002 (26,579 individuals), which can reputedly be related to the collapse of submerged prairies and moderately more stable fish assemblages both in terms of species diversity and relative abundance. In particular, a huge progressive increase in the number of coots was observed: from 9000 to 25,900 individuals in the southern portion of Lake Garda between 1997 and 2002. As highlighted by Giardino et al. (2007a), the daily frequency of catamarans increased significantly in the period investigated, suggesting a not-negligible role in the destructuring and the weakening processes that have affected the stability of the macrophyte communities.

By stratifying the investigated area on the basis of water depth (0-8 m below air-water interface) we highlighted a considerable shift of macrophyte mats towards greater water depths (Fig. 3b). Moreover, as revealed by several authors both in lentic and lotic environments, the submerged macrophytes prevent and reduce the impact of the erosion and sediment re-suspension processes (James, and Barko 1990; Vermaat et al. 2000; Horppila, and Nurminen 2001; Riis, and Biggs 2003). In this context, we argued that the revealed increase in mean plant-colonized depths could be considered an outcome of the gradual loss of vegetation cover that can in turn determine dramatic feedbacks on the condition of the aquatic plant mats itself.

On the other hand, over the last 13 years, Lake Garda has experienced rapid variations in WT and WLF, which 
a)
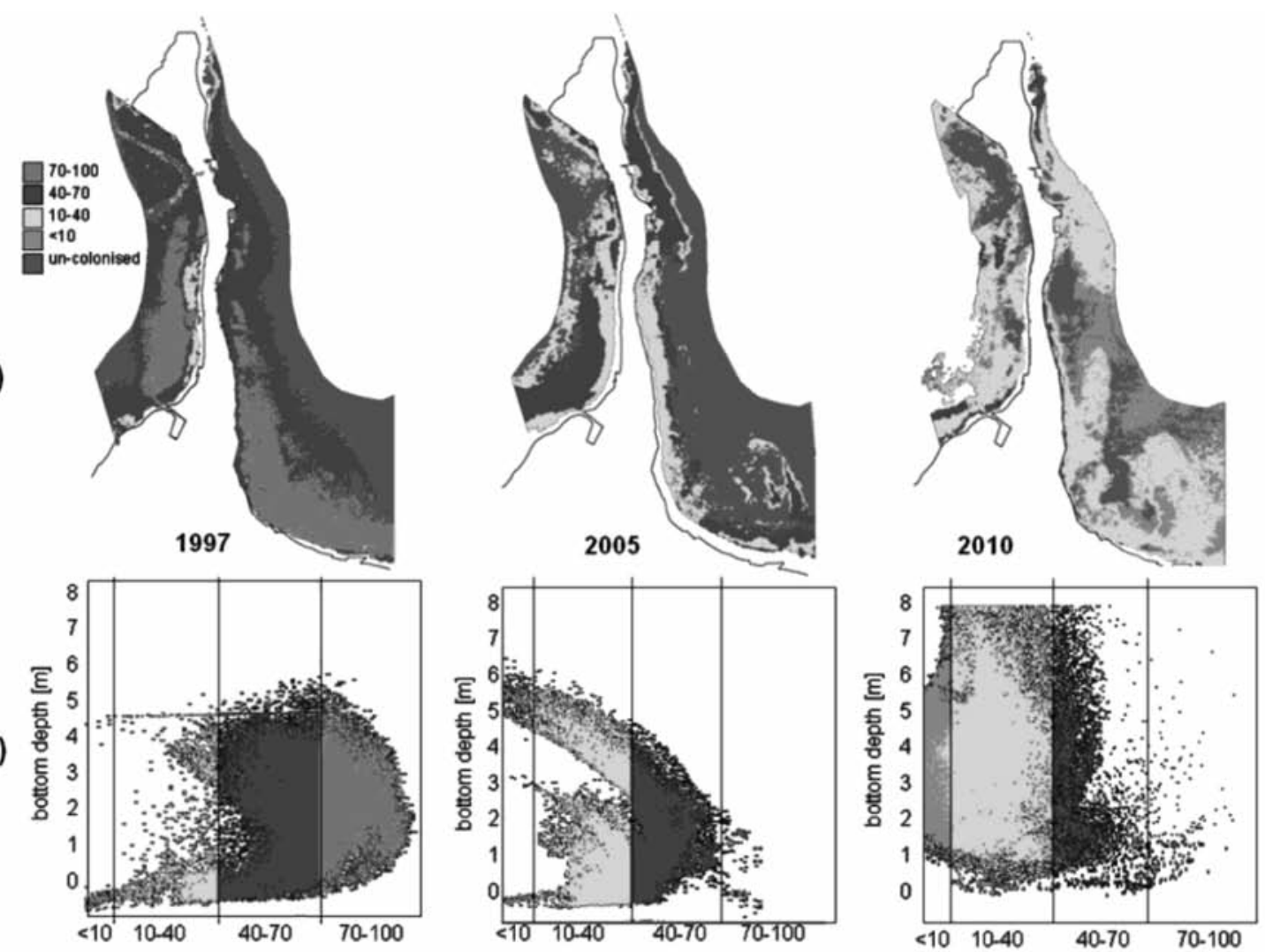

Fig. 3. a) Maps of the substrates from MIVIS data acquired in 1997, 2005 and 2010 on the basis of five classes of macrophyte cover in percentage: un-colonized (i.e. sand), sparse ( $0-10 \%$ cover), moderate ( $10-40 \%$ cover), dense ( $40-70 \%$ cover) and extensive ( $>70 \%)$; b) distribution matrix of bottom depth values versus macrophyte cover classes.

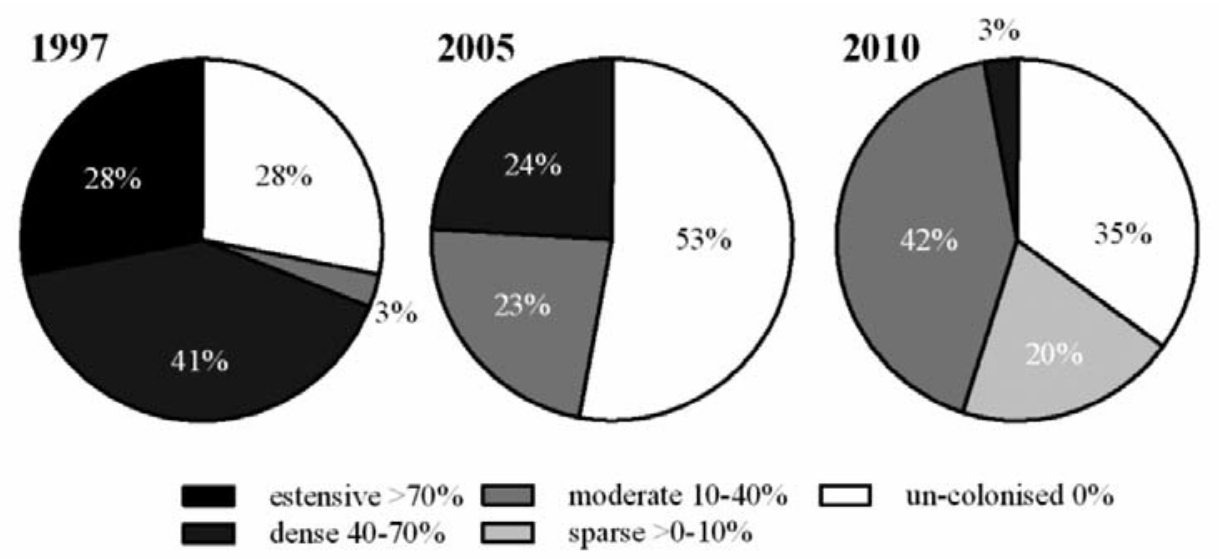

Fig. 4. Distributions of sand and macrophyte cover classes (see text and Fig. 3 for further information) derived from MIVIS for the investigated dates. 
are mutually negatively correlated: through the macrophyte growing season (June to September), there is a significant inverse relationship between WT and WLF delta. The macrophyte cover-abundance trend reflects the variations in WT: the lowest values of macrophyte representativeness $(47 \%)$ were recorded in 2005 following a 5-year period of low WT (Tab. 2; Figs 2 and 4), while data for the years 1997 and 2010 showed slightly higher values (72 and 65\%, respectively). In particular, between 2005 and 2010 we observed a slight macrophyte recovery in terms of area colonized, although in 2010 most of the plant-colonized area featured very low density $(<40 \%$; Fig. 4). On the whole, these findings correspond to those verified by several authors who clarified the ability of aquatic macrophytes to control WT levels (Kufel, and Kufel 2002; van Donk, and van de Bund 2002; Bracchini et al. 2009); furthermore Scheffer (1998) suggested the existence of a direct feedback system modeling the relations between turbidity and submerged vegetation. Therefore, the progressive loss of dense macrophyte stands is coupled with an increase in WLF, which, in turn, is strongly influenced by the steady decrease in the minimum water level (see Figs 2 and 4). We suggest that the water table reductions could enhance the competitive effects of phyto-plankton on submerged vegetation favoring the displacement or the exclusion of phanerogams and charophytes in Lake Garda that could be considered as a trophic changing basin (Salmaso 1996; Salmaso, and Mosello 2010). In fact, over the last 35 years Lake Garda clearly witnessed a worsening of the trophic condition with a significant increase in phosphorous content reaching a concentration peak in 2005 (Salmaso 2010; Salmaso, and Mosello 2010). Consequently, significant modifications have affected the lake's phytoplankton community thus leading to periodic blooms of filamentous cyanobacteria, especially in the southern portion of the lake (for further information, see Salmaso 2005, 2010).

\section{CONCLUSIONS}

In the study area, the loss of well-structured submerged vegetation is coupled with a clear increase in unvegetated or sparsely vegetated substrates. Our data showed that the southern portion of Lake Garda is losing its typical submerged macrophyte communities, which are being replaced by destructured stands, probably due to the decrease in WT and the increase in WLF. In addition, faunal data (especially winter water bird numbers), the rising nutrient content of waters and the increased impact of navigation, intense grazing, algal blooms and mechanical perturbations hindered the growth of phanerogames and charophytes, and favoured the development of dense coenoses such as elodeids (i.e., L. major) and epiphytic macroalgae (i.e., Spirogyra sp., Zygnema sp., and
Mougeotia sp.) which are more demanding in terms of nutrient availability (Bornette, and Puijalon 2011).

On the whole, this work has increased knowledge of macrophyte diversity and relative abundance in the southern portion of Lake Garda, focusing on the small timescale trends of the submerged prairies in the littoral zone of the Sirmione Peninsula. This kind of investigation allows us to recover and integrate bio-physical-chemical data sets (in particular long-term limnological studies) in the absence of mutual diachronic macrophyte surveys, with important repercussions on the conservation and the sustainable use of natural lacustrine resources. Furthermore, the results obtained from this work have allowed us to improve the performance of the bio-optical model which is a suitable tool for monitoring submerged vegetation. As it is parameterized now, the model is ready to be run in the future with new hyperspectral acquisition. These methods, based on remotely sensed data, provide reliable results, supported by ground truthing, cost effective and have implications for lake management.

\section{ACKNOWLEDGMENTS}

This study would have not been possible without the scientific support of M. Bartoli (University of Parma) and the technical assistance of M. Musanti (CNR-IREA) and G.L. Fila (CRA Municipality of Sirmione). MIVIS data were acquired by Blom CGR (Parma, Italy). Physicochemical in situ data were kindly provided by ASL Brescia. We thank I. Confortini (Province of Verona) and V. Longoni (University of Pavia) for fish and ornithological data, respectively. We are very grateful to R. Mackay and D. Stroppiana for the revision of the manuscript. We acknowledge the anonymous reviewers for their valuable comments.

\section{REFERENCES}

Barillé L, Robin M, Harin N, Bargain A, and Launeau P. 2010. Increase in seagrass distribution at Bourgneuf Bay (France) detected by spatial remote sensing. Aquat. Bot. 92: 185-194.

Bell SS, Fonseca MS, and Stafford NB. 2006. Seagrass ecology: New contributions from a landscape perspective. In: Larkum AWD, Orth RJ, and Duarte CM (Eds.), Seagrasses: biology, ecology and conservation. Springer - Dordrecht: 625-645.

Bianchini F, Bertoldi G, and Tessari M. 1974. Floristica e fitosociologia delle macrofite. In: Indagini sul lago di Garda. Quaderni IRSA, CNR, 18. Roma: 225-240.

Bolpagni R, Pierobon E, Longhi D, Nizzoli D, Bartoli M, Tomaselli M, and Viaroli P. 2007. Diurnal exchanges of $\mathrm{CO}_{2}$ and $\mathrm{CH}_{4}$ across the water-atmosphere interface in a water chestnut meadow (Trapa natans L.). Aquat. Bot. 87: 43-48.

Bornette, G., and S. Puijalon. 2011. Response of aquatic plants to abiotic factors: a review. Aquat. Sci. 73: 1-14.

Borsani G, and Contorbia S. 2000. Indagine conoscitiva delle macrofite sommerse nel Lago di Garda e piano per la loro gestione. Autorità di Bacino del Fiume Po, Parma, Italy: 127 pp. 
Bracchini L, Dattilo AM, Hull V, Loiselle SA, Tognazzi A, and Rossi C. 2009. Modelling Upwelling Irradiance using Secchi disk depth in lake ecosystems. J. Limnol. 68 (1): 83-91.

Buchan LAJ, and Padilla DK. 2000. Predicting the likelihood of Eurasian water milfoil presence in lakes, a macrophyte monitoring tool. Ecol. Appl. 10: 1442-1455.

Capers RS, Selsky R, Gregory JB, and White JC. 2007. Aquatic plant community invisibility and scale-dependent patterns in native and invasive species richness. Ecology 88(12): 3135-3143.

Cavazzini A, Miccadei E, Silvestri F, Ferrarini A, and Zaccarelli N. 2000. Hyperspectral MIVIS scanner data integrated into a GIS for an industrial area. International Archives of Photogrammetry and Remote Sensing. Vol. XXXIII, Part B7. Amsterdam, 236-242.

Ciutti F, Beltrami ME, Confortini I, Ciafanelli S, and Cappelletti C. 2011. Non-indigenous invertebrates, fish and macrophytes in Lake Garda (Italy). J. Limnol. 70: 1-6.

Dierssen HM, Zimmerman RC, Drake LA, and Burdige D. 2010. Benthic ecology from space: optics and net primary production in seagrass and benthic algae across the Great Bahama Bank. Mar. Ecol. Prog. Ser. 411: 1-15.

Directive. Directive 1992/43/EEC of the European Parliament and of the council of 21 May 1992 on the conservation of natural habitats and of wild fauna and flora. Official Journal of the European Communities 1992.

Directive. Directive 2000/60/EC of the European Parliament and of the council of 23 October 2000 establishing a framework for community action in the field of water policy. Official Journal of the European Communities 2000.

Duarte CM. 1987. Use of echosounder tracings to estimate aboveground biomass of submerged plant in lakes. Can. J. Fish. Aquat. Sci. 44: 732-735.

Duffy JE. 2006. Biodiversity and the functioning of seagrass ecosystems. Mar. Ecol. Prog. Ser. 311: 233-250.

Fonseca M, Whitfield PE, Kelly NM, and Bell SS. 2002. Modeling seagrass landscape pattern and associated ecological attributes. Ecol. Appl. 12: 218-237.

Fyfe SK. 2003. Spatial and temporal variation in spectral reflectance: Are seagrass species spectrally distinct? Limnol. Oceanogr. 48: 464-479.

Gacia E, Chappuis E, Lumbreras A, Riera JL, and Ballestreros E. 2009 Functional diversity of macrophyte communities within and between Pyrenean lakes. J. Limnol. 68(1): 2536.

Giardino C, Bartoli M, Candiani G, Bresciani M, and Pellegrini L. 2007a. Recent changes in macrophyte colonisation patterns: an imaging spectrometry-based evaluation of southern Lake Garda (northern Italy). J. Appl. Remote Sens., Vol. 1, 011509. doi: 10.1117/1.2834807.

Giardino C, Brando VE, Dekker AG, Strömbeck N, and Candiani G. 2007b. Assessment of water quality in lake garda (Italy) using hyperion. Remote Sens. Environ. 109: 183-195.

Giardino C, Bresciani M, Candiani G, and Gagliano S. 2008. BOMBER: una procedura IDL per la stima automatica di parametri di qualità dell'acqua da dati ottici telerilevati. 12a National Conference ASITA, L'Aquila, Italy, 21-24 October 2008: 1231-1236.

Gillanders BM. 2006. Seagrass, fish and fisheries. In: Seagrass: Biology, Ecology and Conservation. (Eds. AWD Larkum,
RJ Orth, and CM Duarte) Springer, Dorcdrecht, The Netherlands: 503-536.

Heblinski J, Schmieder K, Heege T, Agyemang TK, Sayadyan H, and Vardanyan L. 2010. High-resolution satellite remote sensing of littoral vegetation of Lake Sevan (Armenia) as a basis for monitoring and assessment. Hydrobiologia 661(1): 97-111.

Horppila J, and Nurminen L. 2001. The effect of an emergent macrophyte (Typha angustifolia) on sediment resuspension in a shallow north temperate lake. Freshwater Biol. 46: 1447-1455.

Hunter PD, Gilvear DJ, Tyler AN, Willby NJ, and Kelly A. 2010 Mapping macrophytic vegetation in shallow lakes using the Compact Airborne Spectrographic Imager (CASI). Aquat. Conserv.: Mar. Freshwater Ecosyst. 20(7): 717-727.

Jaeger P, Pall K, and Dumfarth E. 2004. A method of mapping macrophytes in large lakes with regard to the requirements of the Water Framework Directive. Limnologica 34(1-2): 140-146.

Jakubauskas M, Kindscherb K, Fraserb A, Debinskic D, and Pricea KP. 2000. Close-range remote sensing of aquatic macrophyte vegetation cover. Int. J. Remote Sens. 21(18): 3533-3538.

James WF, and Barko JW. 1990. Macrophyte influences on the zonation of sediment accretion and composition in a northtemperate lake. Arch. Hydrobiol. 20: 129-142.

Jupp BP, and Spence DHN. 1977. Limitations of macrophytes in a eutrophic lake, Loch Leven. II. Wave action, sediments and waterfowl grazing. J. Ecol. 65: 431-446.

Kotchenova SY, Vermote EF, Matarrese T, and Klemm FJ Jr. 2006. Validation of a vector version of the $6 \mathrm{~S}$ radiative transfer code for atmospheric correction of satellite data. Part I: Path radiance. Appl. Opt. 45: 6762-6774.

Kotchenova SY, and Vermote EF. 2007. Validation of a vector version of the $6 \mathrm{~S}$ radiative transfer code for atmospheric correction of satellite data. Part II. Homogeneous Lambertian and anisotropic surfaces. Appl. Opt. 46(20): 4455-4464.

Kufel L, and Kufel I. 2002. Chara beds acting as nutrient sinks in shallow lakes - a review. Aquat. Bot. 72: 249-260.

Lodge DM. 1991. Herbivory on freshwater macrophytes. Aquat. Bot. 41: 195-224.

Ludovisi A, Pandolfi P, and Taticchi MI. 2004. A proposed framework for the identification of habitat utilisation patterns of macrophytes in River Po catchment basin lakes (Italy). Hydrobiologia 523: 87-101.

McCreary NJ. 1991. Competition as a mechanism of submerged macrophyte community structure. Aquat. Bot. 41: 177-194.

Murphy KJ, and Eaton JW. 1983. Effects of pleasure-boat traffic on macrophyte growth in canals. J. Appl. Ecol. 20: 713-729.

Oggioni A, Buzzi F, and Bolpagni R. 2011. Indici macrofitici per la valutazione della qualità ecologica dei laghi: MacroIMMI e MTIspecies. In: AA.VV. Indici per la valutazione della qualità ecologica dei laghi. Report CNR - ISE, 03-11: $164 \mathrm{pp}$.

Orth RJ, and MooreKA. 1983. Submersed vascular plants: techniques for analyzing their distribution and abundance. Mar. Technol. Soc. J. 17: 38-52.

Ozesmi SL, and Bauer ME. 2002. Satellite remote sensing of wetlands. Wetlands Ecol. Manage. 10(5): 381-402.

Phinn S, Roelfsema C, Dekker A, Brando V, and Anstee J. 2008. 
Mapping seagrass species, cover and biomass in shallow waters: An assessment of satellite multispectral and airborne hyper-spectral imaging systems in Moreton Bay (Australia). Remote Sens. Environ. 112:3413-3425.

Pierobon E, Bolpagni R, Bartoli M, and Viaroli P. 2010. Net primary production and seasonal $\mathrm{CO}_{2}$ and $\mathrm{CH}_{4}$ fluxes in a Trapa natans L. meadow. J. Limnol. 69 (2): 225-234.

Riis T, and Biggs BJF. 2003. Hydrologic and Hydraulic Control of Macrophyte Establishment and Performance in Streams. Limnol. Oceanogr. 48: 1488-1497.

Salmaso N. 1996. Seasonal variation in the composition and rate of change of the phytoplankton community in a deep subalpine lake (Lake Garda, Northern Italy). An application of nonmetric multidimensional scaling and cluster analysis. Hydrobiologia 337: 49-68.

Salmaso N. 2005. Effects of climatic fluctuations and vertical mixing on the interannual trophic variability of Lake Garda, Italy. Limnol. Oceanogr. 50: 553-565.

Salmaso N, Boscaini A, Cappelletti C, and Ciutti F. 2009. Le condizioni di salute del Lago di Garda: aggiornamento dello stato delle conoscenze sui carichi di nutrienti algali e sulle componenti biologiche della zona pelagica e litorale. Proceedings of the conference" Problematiche ambientali del Lago di Garda. Approfondimenti e proposte di risanamento, Torri del Benaco, March 13th 2009, 49-88.

Salmaso N. 2010. Long-term phytoplankton community changes in a deep subalpine lake: responses to nutrient availability and climatic fluctuations. Freshwater Biol. 55: 825846.

Salmaso N, and Mosello R. 2010. Limnological research in the deep southern subalpine lakes: synthesis, directions and perspectives. Adv. Oceanogr. Limnol. 1: 29-66.

Sauro U. 2001. La macchina idraulica. In: U. Sauro, C. Simoni, E. Turri, and G.M. Varanini (Eds). Il Lago di Garda. Cierre Edizioni. Caselle di Sommacampagna: 496 pp.

Schaumburg J, Schranz C, Stelzer D, and Hofmann G. 2007. Action Instructions for the ecological Evaluation of Lakes for Implementation of the EU Water Framework Directive: Makrophytes and Phytobenthos. Bavarian Environment Agency.

Scheffer M. 1998. Ecology of Shallow Lakes. Chapman and Hall, London: 357 pp.

Scheffer M, Hosper SH, Meijer ML, Moss B, and Jeppesen E. 1993. Alternative equilibria in shallow lakes. Trends Ecol.
Evol. 8: 275-279.

Scheffer M, and Carpenter SR. 2003. Catastrophic regime shifts in ecosystems: linking theory to observation. Trends Ecol. Evol. 18: 648-656.

Scheffer M, and Jeppesen E. 2007. Regime shifts in shallow lakes. Ecosystems 10: 1-3.

Shea K, and Chesson P. 2002. Community ecology theory as a framework for biological invasions. Trends Ecol. Evol. 17: 170-176.

Silva,TSF, Costa MPF, Melack JM, and Novo EMLM. 2008. Remote sensing of aquatic vegetation: theory and applications. Environ. Monit. Assess. 140: 131-145.

Smart AC, Harper DM, Malaisse F, Schmitz S, Coley S, and Gouder de Beauregard AC. 2002. Feeding of the exotic Louisiana red swamp crayfish, Procambarus clarkii (Crustacea, Decapoda), in an African tropical lake: Lake Naivasha, Kenya. Hydrobiologia, 488 (Dev. Hydrobiol. 168): 129-142.

van Donk E, and van de Bund WJ. 2002. Impact of submerged macrophytes including charophytes on phyto- and zooplankton communities: allelopathy versus other mechanisms. Aquat. Bot. 72: 261-274.

Vermaat JE, Santamaria L, and Roos PJ. 2000. Water flow across and sediment trapping in submerged macrophyte beds of contrasting growth form. Arch. Hydrobiol. 148: 549-562.

Vermote EF, Tanrè D, Deizè JL, Herman M, and Morcrette JJ. 1997. Second Simulation of the Satellite Signal in the Solar Spectrum, 6S: An Overview. Trans. Geo. Remote Sens. 35: 675-686.

Vis C, Hudon C, and Carignan R. 2003. An evaluation of approaches used to determine the distribution and biomass of emergent and submerged aquatic macrophytes aver large spatial scales. Aquat. Bot. 77: 187-201.

Wabnitz CC, Andrefouet S, Torres-Pulliza D, Mueller-Karger FE, and Kramer PA. 2008. Regional-scale seagrass habitat mapping in the Wider Caribbean region using Landsat sensors: Applications to conservation and ecology. Rem. Sens. Environ. 112: 3455-3467.

Wiegleb G. 1983. Einige Bemerkungen zur Wasserpflanzenflora des Gardasee-Gebietes. Ber. Bayer. Bot. Ges. 54: 123125 .

Wilson SD, and Keddy PA. 1991. Competition, survivorship and growth in macrophyte communities. Freshwater Biol. 25: 331-337. 